\title{
PROSPEK USAHA PETERNAKAN AYAM BURAS BRAKEL KRIEL-SILVER SEMIINTENSIF DI KOTA PALOPO
}

\author{
Goso $^{1}$, M. Risal ${ }^{2}$ \\ ${ }^{I}$ Dosen Sekolah Tinggi Ilmu Ekonomi Muhammadiyah Palopo \\ ${ }^{2}$ Mahasiswa Program Doktor Manajemen Pemasaran Universitas Padjadjaran
}

\begin{abstract}
Abstrak: Penelitian ini mengkaji profil usaha menganalisis prospek usaha peternakan Ayam buras Brakel kriel-silver di kota Palopo berdasarkan komoditas usaha dan teknologi budidaya serta menentukan strategi pengembangan peternakan Ayam buras yang sesuai dengan potensi dan daya dukung lingkungan peternakan di Kota Palopo.

Aspek pasar dinyatakan layak, terdapat peluang pasar yang cukup besar dan harga yang ditawarkan kompetitif serta strategi pemasaran yang digunakan dapat mengungguli pesaing dari segi kualitas ayam buras, waktu pengiriman dan harga yang ditawarkan. Aspek teknis produk memiliki karakteristik unggul, kapasitas memenuhi target penjualan yang telah ditetapkan sesuai proses dan fasilitas yang digunakan, lokasi tempat pendirian usaha merupakan lokasi yang terbaik untuk mendirikan usaha. Aspek legal dan lingkungan terdapat solusi pengelolaan limbah akibat pendirian dan operasi usaha sehingga tidak mengganggu lingkungan sekitar. Analisis kelayakan aspek sumber daya manusia dinyatakan layak karena mempunyai bentuk struktur organisasi dengan pembagian tugas yang jelas tenaga kerja yang cukup untuk menjalankan operasional dan adanya kejelasan uraian jabatan dan spesifikasinya untuk setiap jabatan. Kelayakan aspek finansial dengan menggunakan metode Payback Periode dan terbukti lebih pendek dari pada waktu analisis usaha peternakan ayam buras, yaitu 2 tahun 2 bulan. Nilai Net Present Value lebih besar dari nol, Nilai dari Interest Return of Rate lebih besar dari pada nilai Minimum Attractive Rate Of Return. Sehingga analisis kelayakan aspek finansial usaha dapat dinyatakan layak karena memenuhi syarat kelayakan.
\end{abstract}

Kata Kunci : Ayam Buras, Ayam Arab, Ayam Kampung, Analisis Prospek Usaha

\section{PENDAHULUAN}

Subsektor peternakan yang berwawasan agribisnis merupakan upaya sistematis dalam memainkan peranan yang aktif dan positif di dalam pembangunan nasional, untuk meningkatkan pertumbuhan ekonomi, pemerataan dan stabilitasi nasional. Salah satu peran penting dari subsektor peternakan dalam pembangunan adalah dalam rangka mendorong pertumbuhan dan dinamika ekonomi pedesaan. Terdapat 3 (tiga) pendekatan yang akan mewarnai pembangunan subsektor peternakan dalam era reformasi yaitu pendekatan agribisnis, pendekatan keterpaduan dan pendekatan sumberdaya wilayah.

Ayam Arab merupakan jenis ayam buras keturunan Ayam Brakel Kriel-Silver dari Belgia, disebut Ayam Arab karena dua hal: pejantannya memiliki daya seksual yang tinggi dan keberadaannya di Indonesia melalui telurnya yang dibawa oleh orang yang menunaikan ibadah haji dari Mekah. Ketertarikan masyarakat pada Ayam buras jenis Ayam Arab ini karena produksi telurnya tinggi, mencapai 190-250 butir per tahun dengan berat telur 42,3 gram. Kuning telur lebih besar volumenya, mencapai $53,2 \%$ dari total berat telur. Sehingga ayam buras jenis ini sangat potensial untuk dikembangan pada skala semiintensif maupun intensif.

Budidaya ayam buras memiliki keterkaitan dengan industri hulu di bidang perunggasan yang meliputi industri pakan, industri obat dan vaksin hewan, industri pembibitan, dan industri peralatan peternakan. Budidaya ayam buras ini dapat 
dilakukan sebagai usaha mandiri baik yang bersifat komersial maupun usaha rakyat

Tantangan dan hambatan dalam usaha peternakan ayam buras Arab Brakel Kriel-Silver antara lain manajemen pemeliharaan yang lemah, mahalnya bibit day old chicken (DOC), sistem pemeliharaan, kandang dan peralatan, tidak ada kepastian waktu jual dan pemasaran hasil ternak. Pemeliharaan ayam buras pada umumnya masih dilakukan secara ekstensif (tradisional), berkeliaran sepanjang hari di pekarangan, kebun maupun di jalanan, dan mencari makan pada timbunan sampah, selokan, tepi saluran air dan jalan, pemberian pakan tidak seimbang baik kualitas maupun kuantitasnya, dan pencegahan penyakit belum Optimal (Gunawan, 2012) sehingga produktivitasnya rendah, karena pemeliharaan masih sederhana dan belum memperhatikan tata laksana yang baik. Upaya meningkatkan produktivitas ayam buras dapat dilakukan melalui introduksi teknologi pemeliharaan dari ekstensif-tradisional menjadi semiintensif atau intensif (Zakaria 2004) yaitu dengan melaksanakan "Sapta Usaha" ayam buras, yang meliputi pemilihan bibit, pencegahan penyakit, perkandangan, pemberian pakan dengan gizi seimbang, sistem reproduksi, pascapanen, pemasaran, dan manajemen usaha (Sartika 2005).

\section{BAHAN DAN METODE}

Ayam buras (ayam bukan ras) merupakan unggas lokal yang populasinya tersebar di seluruh wilayah Indonesia, seperti ayam Kedu, Nunukan, Lampung dan Pelung, biasanya dipelihara secaara bebas dan untuk usaha sambilan. Ayam buras adalah keturunan dari Gallus gallus atau Red Jungle Fowl yang sudah mengalami domestikasi selama puluhan tahun. (Crawford, 1990).

Ayam Arab (Brakel kriel-silver) adalah salah satu jenis ayam kampung yang ada di Indonesia, yang memiliki keunggulan sebagai petelur. Ayam Arab merupakan keturunan Ayam Brakel Kriel-Silver dari Belgia, disebut Ayam Arab karena dua hal: pejantannya memiliki daya seksual yang tinggi dan keberadaannya di Indonesia melalui telurnya yang dibawa oleh orang yang menunaikan ibadah haji dari Mekah. Ciri lain ayam arab adalah pejantannya pada umur 1 minggu sudah tumbuh jengger, dan betina induk tidak memiliki sifat mengeram, produksi telurnya tinggi, mencapai 190-250 butir per tahun dengan berat telur 42,3 gram. Dari penampilan tubuhnya, tinggi Ayam Arab dewasa mencapai $35 \mathrm{~cm}$ dengan bobot 1,5-2 kg. Kepalanya mempunyai jengger berbentuk tunggal dan bergerigi. Ayam ini berbulu tebal. Bulu di sekitar leher berwarna kuning dan putih kehitaman. Warna bulu badannya putih bertotol-totol hitam. Kokok suara jantan nyaring. http://www.infoternak.com/ayam-arab/

Karena pemeliharaanya masih secara Ekstensif (tradisional), makanya produktivitasnya masih rendah, hasilnya pun tidak terlalu bagus. Unggas lokal tersebut berpotensi besar untuk dikembangkan karena mempunyai peranan yang sangat penting dalam memenuhi kecukupan gizi keluarga, peningkatan pendapatan keluarga dan dijadikan sebagai tabungan bagi peternak. Pemeliharaan dan pemasaran ayam buras sangat sederhana sedangkan dari pendapatan sangat menguntungkan bagi peternak (Sarwono, 2012) 


\section{Analisis Prospek Pasar}

Prospek merupakan kondisi yang akan dihadapi oleh perusahaan dimasa yang akan datang baik kecendrungan untuk meningkatkan atau menutup. Kondisi ini dipengaruhi oleh berbagai peluang dan ancaman yang dihadapi. Kelemahan dan kekuatan yang dimiliki perusahaan sehingga diperlukan perencanaan dan perumusan strategis perusahaan secara baik. Menururt Paul R. Krugman (2003:121) menyatakan bahwa "Prospek adalah peluang yang terjadi karena adanya usaha seseorang dalam memenuhi kebutuhan hidupnya juga untuk mendapatkan profit atau keuntungan". Menurut Djasmin (2004:28) Prospek adalah "kebijakan perusahaan untuk meningkatkan kinerja penjualan dengan meraih peluang yang ada serta mengatasi berbagai hambatan dan ancaman baik dalam jangka panjang maupun jangkan pendek".

\section{Analisis Prospek Teknis}

Analisis aspek teknis atau yang biasa lebih dikenal dengan aspek operasi adalah kesiapan suatu usaha (perusahaan) dalam menjalankan usaha dengan menilai ketepatan lokasi, luas produksi, dan layout serta kesiagaan mesin mesin yang akan digunakan.

Menurut Heizer dan Render (2006:4), "Operation Management is the set of activities that creates value in the form of goals and service by transforming inputs into outputs", yang artinya Manajemen Operasi adalah sekumpulan aktivitas yang menciptakan nilai lebih dalam bentuk layanan dan hasil atau tujuan dengan cara mentransformasikan input menjadi output"
Menurut Umar (2005) Manajemen Operasional adalah suatu fungsi atau kegiatan manajemen yang meliputi perencanaan, organisasi, staffing, koordinasi, pengarahan dan pengawasan terhadap operasonal perusahaan.

Menurut Kasmir dan Jakfar (2012:150), Aspek Operasi adalah untuk menilai kesiapan perusahaan dalam menjalankan usahanya dengan menilai ketepatan lokasi, luas produksi, dan layout serta kesiagaan mesin-mesin yang akan digunakan.

\section{Analisis Aspek Finansial}

Menurut Fuad, et al (2006:222), Manajemen keuangan adalah aktivitas yang terkait dengan perencanaan dan pengendalian perolehan serta pendistribusian asset-asset keuangan perusahaan. Menurut Ernie dan Kurniawan (2005:14), manajemen keuangan adalah kegiatan manajemen berdasarkan fungsinya yang pada intinya untuk memastikan bahwa kegiatan bisnis yang dilakukan mampu mencapai tujuannya secara ekonomis, yaitu diukur berdasarkan profit.

Menurut Kasmir dan Jakfar (2012:90), penilaian dalam aspek keuangan meliputi hal-hal seperti:

1. Sumber-sumber dana yang akan diperoleh

2. Kebutuhan biaya investasi

3. Estimasi pendapatan dan biaya investasi selama beberapa periode termasuk jenisjenis dan jumlah biaya yang akan dikeluarkan selama umur investasi.

4. Proyeksi neraca dan laporan laba rugi untuk beberapa periode ke depan.

5. Kriteria penilai investasi.

6. Rasio keungan yang digunakan untuk menilai kemampuan perusahaan 


\section{Usaha Peternakan Ayam Buras}

Ayam buras merupakan salah satu unggas lokal yang umumnya dipelihara petani di pedesaan sebagai penghasil telur tetas, telur konsumsi, dan daging. Selain dapat diusahakan secara sambilan, mudah dipelihara dengan teknologi sederhana, dan sewaktu-waktu dapat dijual untuk keperluan, unggas ini mempunyai prospek yang menjanjikan, baik secara ekonomi maupun sosial, karena merupakan bahan pangan bergizi tinggi (Gunawan dan Sundari 2003) serta permintaannya cukup tinggi (Bakrie et al. 2003). Pangsa pasar nasional untuk daging dan telur ayam buras masing-masing mencapai $40 \%$ dan 30\%. Hal ini dapat mendorong peternak kecil dan menengah untuk mengusahakan ayam buras sebagai penghasil daging dan telur (Rohaeni et al. 2004).

Produktivitas ayam buras yang dipelihara secara tradisional masin rendah, antara lain karena tingkat mortalitas tinggi, pertumbuhan lambat, produksi telur rendah, dan biaya pakan tinggi (Zakaria 2004). Produksi telur ayam buras yang dipelihara secara tradisional berkisar antara 40-45 butir/ekor/tahun, karena adanya aktivitas mengeram dan mengasuh anak yang lama, yakni 107 hari (Sulandari et al. 2007).

Untuk meningkatkan populasi, produksi, produktivitas, dan efisiensi usaha tani ayam buras, pemeliharaannya perlu ditingkatkan dari tradisional ke arah agribisnis (Zakaria 2004; Yudohusodo dalam Iriyanti et al. 2005). Pengembangan ayam buras secara semiintensif dan intensif dengan pemberian pakan yang berkualitas serta pencegahan dan pengendalian penyakit, terutama tetelo (ND), cacingan, dan kutu, cukup. Perbaikan tata laksana pemeliharaan dari tradisional ke intensif dapat meningkatkan daya tetas sampai $80 \%$, frekuensi bertelur menjadi 7 kali/tahun, dan menurunkan kematian hingga 19\% (Sartika, 2005)

Teknik penarikan sampel dalam penelitian ini adalah Simple Random Sampling, dengan jumlah sample responden masing-masing; Kecamatan Wara Timur $=18$ responden; Kecamatan Tellu Wanua=18 responden; Kecamatan Wara Utara 17 responden; Kecamatan Wara $=17$ responden dan Kecamatan Bara $=18$ responden. Metode pengambilan data yang dilakukan dengan cara mencatat secara sistematis hasil pengamatan terhadap kejadian-kejadian yang diselidiki selama penelitian (Marzuki, 2002).D

Data yang dibutuhkan dalam penelitian ini terdiri dari data primer dan data sekunder. Data primer berkaitan dengan data kapasitas dan produksi. Data hasil kuesioner digunakan untuk mendukung analisis SWOT. Data penelitian yang terkumpul setelah diolah kemudian dianalisis dengan menggunakan analisis deskriptif dan analisis SWOT (Strengths, Weaknesses, Opportunities, Threats) untuk melihat tingkat kekuatan, kelemahan, peluang dan ancaman yang dihadapi dalam budidaya ayam buras untuk kemudian diprediksi kemungkinan pengembangan usaha peternakan Ayam Buras Brakel Kriel Silver di Palopo.

Analisis Secara sistematis dilakukan pada ke- 5 (lima) aspek-aspek terkait usaha yaitu Analisis terhadap aspek pasar, aspek teknis, aspek legal dan lingkungan, aspek sumberdaya manusia dan aspek finansial melalui:

1. Periode pengembalian (PBP/PP). 
2. Periode pengembalian yang didiskontokan (DPBP).

3. Nilai tunai netto (NPV)

4. Internal Rate of Return (IRR) dibandingkan dengan Minimum Attractive Rate Of Return (MARR)

5. Profitability Indeks (PI)

\section{HASIL DAN PEMBAHASAN}

Proses pengambilan keputusan strategis selalu berkaitan dengan latar belakang, potensi dan permasalahan yang ada baik secara internal berupa kekuatan dan kelemahan maupun secara eksternal berupa peluang dan ancaman. Strategi dan pengembangan usaha budidaya ternak ayam buras di Kota Palopo dilakukan dengan menganalisis faktor-faktor strategis usaha ternak melalui analisis SWOT yaitu menganalisis kekuatan (Strenghts), kelemahan (Weaknesses), peluang (Opportunity) dan ancaman (Threats).

Metodologi penentuan bobot dan rating dalam penilaian Faktor Strategi Internal dan Ekternal dapat dilihat dalam Bab Metodologi penelitian. Matrik faktor strategi internal (kekuatan dan kelemahan) pengembangan usaha budidaya Ayam Buras di Kota Palopo 
Tabel 1.

Matrik Faktor Strategi Internal (IFAS-Internal

Strategic Factors Analysis

Summary) Pengembangan Usaha Budidaya Ayam Buras di Kota Palopo

\begin{tabular}{|c|c|c|c|c|c|}
\hline & Faktor-Faktor Strategi Internal & Bobot & Rating & $\begin{array}{l}\text { Bobot } \mathrm{x} \\
\text { Rating }\end{array}$ & Komentar \\
\hline Ke & zuatan (Strenghts) & & & & \\
\hline 1 & Potensi lahan yang besar & 0,15 & 4 & 0,60 & 9.970,5 hektar \\
\hline 2 & Ketersediaan DOC yang memadai & 0,05 & 3 & 0,15 & $\begin{array}{l}\text { Disepanjang Pantura terdapat } \\
\text { banyak usaha }\end{array}$ \\
\hline & & & & & pembenihan udang \\
\hline 3 & Jumlah tenaga kerja yang memadai & 0,07 & 3 & 0,21 & $\begin{array}{l}\text { Banyaknya usia dan angkatan } \\
\text { kerja di Kota Palopo. }\end{array}$ \\
\hline 4 & $\begin{array}{l}\text { Sarana dan prasarana produksi } \\
\text { tersedia }\end{array}$ & 0,10 & 4 & 0,40 & $\begin{array}{l}\text { Sarana dan prasarana produksi } \\
\text { sangat tersedia }\end{array}$ \\
\hline 5 & Ketersediaan modal & 0,06 & 2 & 0,12 & $\begin{array}{l}\text { Program PLUD yang } \\
\text { memberikan bantuan } \\
\text { permodalan bagi peternak }\end{array}$ \\
\hline 6 & Dukungan Pemerintah & 0,07 & 2 & 0,14 & $\begin{array}{l}\text { Peranan Penyuluh Peternakan } \\
\text { sangat besar dalam usaha } \\
\text { budidaya Ayam Buras }\end{array}$ \\
\hline Kel & mahan (Weaknesses) & & & & \\
\hline 1 & $\begin{array}{l}\text { Menurunnya produksi ternak ayam } \\
\text { buras ekstensif }\end{array}$ & 0,05 & 2 & 0,10 & Sejak tahun 2009 \\
\hline 2 & Kualitas pakan menurun & 0,10 & 1 & 0,10 & Adanya pencemaran \\
\hline 3 & Kualitas SDM rendah & 0,05 & 3 & 0,15 & $\begin{array}{l}\text { Petani ternak sebagian besar } \\
\text { berijasah SLTP }\end{array}$ \\
\hline 4 & Harga bibit mahal & 0,05 & 2 & 0,10 & Diperoleh di Luar Kota Palopo \\
\hline 5 & $\begin{array}{l}\text { Lembaga pengujian mutu belum } \\
\text { representatif }\end{array}$ & 0,10 & 2 & 0,20 & Belum tersedia \\
\hline 6 & Biaya produksi besar & 0,05 & 2 & 0,10 & $\begin{array}{l}\text { Biaya produksi tidak terpenuhi } \\
\text { sehingga tidak dapat } \\
\text { meningkatkan usaha } \\
\text { budidayaAyam Buras }\end{array}$ \\
\hline 7 & $\begin{array}{l}\text { Terbatasnya informasi teknologi } \\
\text { bagi peternak ayam buras }\end{array}$ & 0,05 & 3 & 0,15 & $\begin{array}{l}\text { Informasi tentang } \\
\text { perkembangan teknologi } \\
\text { peternakan masih sangat kurang } \\
\text { diterima peternak }\end{array}$ \\
\hline 8 & Lemahnya penegakan hukum & 0,05 & 4 & 0,20 & $\begin{array}{l}\text { Jaminan keamanan kurang } \\
\text { terjamin }\end{array}$ \\
\hline & Jumlah & $0.99,05$ & & 2,52 & \\
\hline
\end{tabular}


Tabel 3. Daftar Nilai terboboti Tiap Unsur SWOT

Sedangkan Matrik faktor strategi eksternal (peluang dan ancaman) pengembangan usaha budidaya Ternak Ayam Buras tersaji pada Tabel 2. berikut;
Tabel. 2

Matrik Faktor Strategi Eksternal (EFASExternal Strategic Factors Analysis Summary) Pengembangan Usaha Budidaya Ayam Buras di Kota Palopo

\begin{tabular}{|c|c|c|c|c|c|c|c|c|c|}
\hline \multicolumn{4}{|c|}{ Faktor-Faktor Strategi Eksternal } & Bobot & Rating & $\begin{array}{l}\text { Bobot } \\
\text { Ratin }\end{array}$ & \multicolumn{3}{|c|}{ Komentar } \\
\hline \multicolumn{4}{|c|}{ Peluang (Opportunity) } & & & & & & \\
\hline 1 & \multicolumn{3}{|c|}{ Pangsa pasar yang besar } & 0,20 & 4 & 0,80 & \multicolumn{3}{|c|}{$\begin{array}{l}\text { Ayam Buras masih menjadi } \\
\text { primadona }\end{array}$} \\
\hline 2 & \multicolumn{3}{|c|}{$\begin{array}{l}\text { Harga udang yang stabil dan } \\
\text { kompetitif }\end{array}$} & 0,05 & 3 & 0,15 & \multicolumn{3}{|c|}{$\begin{array}{l}\text { Harga ayam Buras lebih } \\
\text { stabil }\end{array}$} \\
\hline 3 & \multicolumn{3}{|c|}{$\begin{array}{l}\text { Preferensi konsumen terhadap } \\
\text { hasil budidaya }\end{array}$} & 0,06 & 3 & 0,18 & \multicolumn{3}{|c|}{$\begin{array}{l}\text { Produksi ayam buras telah dikenal } \\
\text { masyarakat }\end{array}$} \\
\hline 4 & \multicolumn{3}{|c|}{ Sarana transportasi memadai } & 0,04 & 3 & 0,12 & \multicolumn{3}{|c|}{$\begin{array}{l}\text { Lokasi kandang mudah dijangkau } \\
\text { oleh kendaraan }\end{array}$} \\
\hline 5 & \multicolumn{3}{|c|}{ Peluang berusaha yang besar } & 0,10 & 3 & 0,30 & \multicolumn{3}{|c|}{ Tersedianya lahan yang luas } \\
\hline \multicolumn{10}{|c|}{ Ancaman (threats) } \\
\hline 1 & \multicolumn{3}{|c|}{$\begin{array}{l}\text { Menurunnya daya dukung } \\
\text { lingkungan }\end{array}$} & 0,20 & 1 & 0,20 & \multicolumn{3}{|c|}{$\begin{array}{l}\text { Perbaikan lingkungan kandang } \\
\text { dengan dilakukannya rehabilitasi } \\
\text { lahan bekas kandang ayam ras }\end{array}$} \\
\hline 2 & \multicolumn{3}{|c|}{ Keamanan yang kurang terjamin } & 0,05 & 2 & 0,10 & \multicolumn{3}{|c|}{$\begin{array}{l}\text { Koordinasi peternak untuk } \\
\text { menjaga keamanan rendah }\end{array}$} \\
\hline 3 & \multicolumn{3}{|c|}{$\begin{array}{l}\text { Pemberlakuan standarisasi mutu } \\
\text { produk hasil peternakan rendah }\end{array}$} & 0,05 & 2 & 0,10 & \multicolumn{3}{|c|}{$\begin{array}{l}\text { Standarisasi mutu produk kurang } \\
\text { dipahami oleh peternak }\end{array}$} \\
\hline 4 & \multicolumn{3}{|c|}{ Adanya kompetitor } & 0,05 & 3 & 0,15 & \multicolumn{3}{|c|}{$\begin{array}{l}\text { Koordinasi intern peternak } \\
\text { untuk menguatkan kelembagaan }\end{array}$} \\
\hline 5 & \multicolumn{3}{|c|}{$\begin{array}{l}\text { Kurangnya akses terhadap } \\
\text { lembaga permodalan }\end{array}$} & 0,05 & 4 & 0,20 & \multicolumn{3}{|c|}{$\begin{array}{l}\text { Bantuan jaminan permodalan } \\
\text { dengan bunga terjangkau bagi para } \\
\text { peternak kurang }\end{array}$} \\
\hline & \multicolumn{3}{|c|}{ Jumlah } & 1,00 & & 2,50 & & & \\
\hline \multicolumn{2}{|c|}{$\begin{array}{l}\text { Kekuatan } \\
\text { (Strenghts) }\end{array}$} & $\begin{array}{c}\text { Nilai } \\
\text { Terbobot }\end{array}$ & $\begin{array}{l}\text { Kelemahan } \\
\text { (Weaknesses) }\end{array}$ & $\begin{array}{c}\text { Nilai } \\
\text { Terbobot }\end{array}$ & \multicolumn{2}{|c|}{\begin{tabular}{|c|} 
Peluang \\
(Opportunities)
\end{tabular}} & $\begin{array}{c}\text { Nilai } \\
\text { Terbobot }\end{array}$ & $\begin{array}{l}\text { Ancaman } \\
\text { (Threats) }\end{array}$ & $\begin{array}{c}\text { Nilai } \\
\text { Terbobot }\end{array}$ \\
\hline \multicolumn{2}{|c|}{$\mathrm{S} 1$} & 0,60 & $\mathrm{~W} 1$ & 0,10 & \multicolumn{2}{|c|}{$\mathrm{O} 1$} & 0,80 & $\mathrm{~T} 1$ & 0,20 \\
\hline \multicolumn{2}{|c|}{ S2 } & 0,15 & W2 & 0,10 & \multicolumn{2}{|c|}{$\mathrm{O} 2$} & 0,15 & $\mathrm{~T} 2$ & 0,10 \\
\hline \multicolumn{2}{|c|}{ S3 } & 0,21 & W3 & 0,15 & \multicolumn{2}{|c|}{$\mathrm{O} 3$} & 0,18 & $\mathrm{~T} 3$ & 0,10 \\
\hline & 44 & 0,40 & W4 & 0,10 & 0 & & 0,12 & $\mathrm{~T} 4$ & 0,15 \\
\hline & 55 & 0,12 & W5 & 0,20 & 0 & & 0,30 & $\mathrm{~T} 5$ & 0,20 \\
\hline & nlah & $\mathbf{1 , 4 8}$ & & 1,00 & & & 1,55 & & $\mathbf{0 , 7 5}$ \\
\hline
\end{tabular}

7 I Jurnal Equilibrium, Vol.05 No.01 Februari 2015 
Berdasarkan matrik faktor strategi internal (IFAS) dan eksternal (EFAS) pengembangan usaha budidaya Ayam Buras di Kota Palopo yang tersaji pada Tabel 1. dan 5.2, diperoleh bahwa nilai total faktor strategi internal (IFAS) sebesar 2,52 dan eksternal (EFAS) sebesar 2,50; sehingga jika dimasukkan dalam matrik internal eksternal usaha budidaya ternak di Kota Palopo berada dalam posisi sel (segmen) V yang berarti bahwa usaha budidaya ternak ayam Buras berada pada kondisi yang relatif stabil dan kemungkinan dapat terjadi pertumbuhan.

Sedangkan berdasarkan matrik analisis SWOT pengembangan usaha budidaya Ayam Buras di Kota Palopo diperoleh peringkat strategi tiap sel sebagai berikut :

1. Peringkat ke 1 : Strategi SO dengan jumlah nilai terbobot 3,27

- Peningkatan produksi melalui peningkatan introduksi teknologi budidaya Ayam buras secara intensif dan berwawasan lingkungan

- Pengembangan budidaya ternak ayam buras selain ayam buras brakel kriel silver yang mempunyai pangsa pasar yang cukup potensial

- Pengembangan produksi ayam buras dari Day Old Chick (DOC) sampai ke peternakan (pembudidaya ayam buras)

- Pengembangan pasar dengan mengadakan pasar ayam dengan sistem lelang sehingga tidak ada monopoli harga
2. Peringkat ke 2 : Strategi WO dengan jumlah nilai terbobot 2,75

- Mengubah pola pengelolaan kandang secara tradisional ekstensif menjadi pola semi intensif dan intensif guna peningkatan produksi ayam

- Manajemen kualitas lingkungan kandang dan pemberian ransum/pakan

- Penguatan kelompok peternak dalam menyehatkan pola pemasaran ayam

- Pengadaan biibit (DOC) yang bermutu baik

3. Peringkat ke 3 : Strategi ST dengan jumlah nilai terbobot 2,47

- Pengembangan budidaya Ayam Buras dengan menggunakan kandang postal dan panggung untuk memudahkan pengolahan limbah.

- Pemberian bantuan permodalan dengan kredit lunak bagi Peternak guna pengembangan usaha budidaya ayam buras brakel kriel silver.

- Peningkatan keamanan produksi dengan melakukan koordinasi antar peternak

- Konsolidasi internal, penguatan kelompok, antisipasi desakan peruntukkan tata ruang

4. Peringkat ke 4 : Strategi WT dengan jumlah nilai terbobot 1,95

- Penerapan manajemen pengelolaan (penatalaksanaan) budidaya secara arif dengan memperhatikan daya dukung lingkungan kandang

- Penerapan teknologi tepat guna dalam budidaya ayam buras untuk mengatasi menurunan daya dukung lingkungan 
- Pengembangan budidaya ayam buras kualitas super hasil persilangan antar ayam kampong unggulan dengan sistem semiintensif

- Peningkatan produksi dengan memberlakukan standar mutu produk dan keamanan produksi

\section{Kelayakan Aspek Pasar}

Melihat dari hasil peramalan demand dan supply ayam buras, dapat diketahui peluang pasar yang tersedia yang merupakan selisih dari demand dan supply di kota Palopo.Dengan mempertimbangkan kisaran harga pesaing di wilayah Luwu Raya dan Toraja (Kab. Luwu, Kab. Luwu Utara, Kab. Luwu timur, Kota Palopo dan Toraja), berdasarkan data yang terdapat pada Tabel 5.5, harga ayam buras untuk usia 7-8 minggu dengan ukuran berat antara $1,2-1,5 \mathrm{~kg}$ per ekor berada pada kisaran Rp.75.000 Rp.80.000. Dengan menggunakan teknik penentuan harga untuk barang konsumsi berdasarkan Strategi Price Penetration ditentukan bahwa harga jual ayam buras per ekor adalah Rp.65.000. Price Penetration adalah penetapan harga di bawah harga normal. Ini dilakukan bila usaha baru memperkenalkan produk barunya ke pasar di mana terdapat penjual produk yang sama dan persaingan yang cukup tinggi. Hal ini di maksudkan agar barang yang dihasilkan diterima oleh pasar dan dapat bersaing.

Strategi pemasaran yang dipilih adalah berdasarkan aspek lokasi atau tempat (place), pemilik modal menentukan lokasi di sekitar Kota Palopo yang dekat dengan beberapa pasar sasaran, agar dapat meminimalisir biaya transportasi pengiriman ayam buras ke pasarpasar. Selain itu jarak yang lebih dekat dengan pasar dapat meminimalisir jumlah ayam buras yang mati karena stress, sehingga kualitas ayam buras potong yang akan dikonsumsi menjadi lebih segar dan lebih baik dari segi kesehatan.

\section{Kelayakan Aspek Teknis}

Berdasarkan data karakteristik ayam buras, maka dirancanglah karakteristik ayam buras yang akan budidayakan. Untuk usaha peternakan ayam buras yang akan di kelola mempertimbangkan beberapa faktor dan aspek produktivitas dan nilai ekonomis produk di pasaran, sehingga menekankan berat badan ayam buras, produktivitas telor dan proses pertumbuhannya yang cepat. Jenis ayam buras yang terpilih adalah Ayam buras campuran antara jenis ayam Kampung Super dan Brakel kriel-silver

\section{Kelayakan Aspek Legal dan Lingkungan}

Berdasarkan faktor-faktor penentuan badan usaha, bentuk badan usaha yang sesuai untuk pendirian usaha peternakan ayam buras di Kota Palopo adalah Perusahaan Perseorangan (PP). Setelah melihat Daftar Negatif Investasi, usaha peternakan ayam buras tidak termasuk di dalam Daftar Negatif Investasi di kota Palopo. Izin- izin yang perlu dilengkapi sebelum mendirikan usaha peternakan ayam buras terdiri Izin Gangguan (Hinderordonnantie/HO), dan Surat Izin Tempat Usaha (SITU). Sedangkan izin pascakonstruksi meliputi Surat Izin Usaha Perdagangan (SIUP) yang pembuatannya membutuhkan persayaratan diantaranya Kartu Tanda Penduduk (KTP), Nomor Pokok Wajib Pajak (NPWP), Surat Izin Gangguan (Hinderordonnantie/HO), Cash Flow (Neraca 
Perusahaan), Surat Keterangan Domisili Perusahaan (SITU), dan gambar denah lokasi kegiatan usaha.

Limbah yang dihasilkan oleh proses ternak ayam buras adalah kotoran ayam yang berupa limbah padat. Limbah ini dapat dijual kepada pengepul kotoran ternak seharga $\mathrm{Rp} 7500$ per karung, yang kemudian akan didistribusikan ke petani dan masyarakat pekebun yang lebih suka pupuk organic.

Analisis aspek sumber daya manusia terdiri dari perancangan struktur organisasi, struktur tenaga kerja, dan program pelatihan/ penyuluhan.

\section{Kelayakan Aspek Sumber Daya Manusia}

Struktur organisasi perusahaan peternakan ayam buras menggunakan struktur organisasi fungsional Piramida struktur tenaga kerja berdasarkan jenjang manajemen di usaha budidaya Ayam Buras di Kota Palopo.

Pelatihan dan penyuluhan pada usaha budidaya peternakan ayam buras difokuskan kepada pengenalan operasional perusahaan. Pengenalan operasional perusahaan merupakan pelatihan mengenai kegiatan teknis rutin usaha di bidang produksi, distribusi, pengadaan, dan administrasi. Pelatihan ini diberikan satu bulan sekali dengan diadakannya rapat bulanan sebagai media evaluasi dan komunikasi antara pimpinan dan bawahannya agar tercapai tujuan dari perusahaan peternakan ayam buras.

\section{Analisis Aspek Finansial}

Pada aspek finansial akan menjelasakan mengenai penyusunan laporan keuangan, mengukur kinerja finansial, dan melakukan penilaian kelayakan aspek finansial berdasarkan ukuran kinerja finansial.

1. Kelayakan Aspek Finansial

Aspek finansial dikatakan layak apabila Payback Period (PP) dapat dicapai sebelum periode analisis berakhir, nilai Nett Present Value (NPV) positif dan nilai Internal Rate of Return (IRR) lebih besar dari nilai Minimum Attractive Rate of Return (MARR). Proyeksi arus kas usaha budidaya ayam buras di Kota Palopo yang dapat dilihat pada Tabel 5.11. dan rekapitulasi hasil perhitungan kinerja finansial

2. Analisis Kelayakan Aspek Finansial

Berdasarkan hasil perhitungan dengan menggunakan beberapa metode diatas, maka aspek finansial usaha dapat dinyatakan layak karena memenuhi syarat kelayakan, yaitu :

(1) Payback Periode (PP) lebih pendek dari pada waktu analisis usaha peternakan ayam buras, yaitu 2 tahun 2 bulan.

(2) Nilai Net Present Value (NPV) lebih besar dari nol, yaitu sebesar Rp. 79.550.592,-

(3) Nilai dari Interest Return of Rate (IRR) lebih besar dari pada nilai Minimum Attractive Rate Of Return (MARR), yaitu $27,23 \%>12,08 \%$. 
Tabel 4

Arus Kas (Cash Flow)

\begin{tabular}{|c|c|c|c|c|c|c|}
\hline \multirow[b]{2}{*}{ URAIAN } & \multirow[b]{2}{*}{ Tahun ke-0 } & \multicolumn{2}{|l|}{ CASH FLOW } & \multirow[b]{2}{*}{ Tahun ke-3 } & \multirow[b]{2}{*}{ Tahun ke-4 } & \multirow[b]{2}{*}{ Tahun ke-5 } \\
\hline & & Tahun ke-1 & Tahun ke-2 & & & \\
\hline \multicolumn{7}{|l|}{ CASH IN } \\
\hline Pendapatan & & $289,665,000$ & $318,714,750$ & $350,681,963$ & $385,860,257$ & $424,572,895$ \\
\hline TOTAL CASH IN & & $289,665,000$ & $318,714,750$ & $350,681,963$ & $385,860,257$ & $424,572,895$ \\
\hline \multicolumn{7}{|l|}{ CASH OUT } \\
\hline $\begin{array}{l}\text { Investasi Awal (tanpa } \\
\text { tanah) }\end{array}$ & $125,103,000$ & & & & & \\
\hline Biaya Langsung & & $182,400,000$ & $200,160,000$ & $220,536,000$ & $244,004,400$ & $271,134,540$ \\
\hline $\begin{array}{c}\text { Biaya Tak } \\
\text { Langsung }\end{array}$ & & $46,664,700$ & $55,589,166$ & $66,284,536$ & $79,108,855$ & $94,493,314$ \\
\hline Pokok Pinjaman & & $5,020,600$ & $5,020,600$ & $5,020,600$ & $5,020,600$ & $5,020,600$ \\
\hline Bunga Pinjaman & & $2,706,103$ & $2,164,883$ & $1,623,662$ & $1,082,441$ & 541,221 \\
\hline Pajak & & $6,084,821$ & $6,448,134$ & $6,627,767$ & $6,556,117$ & $6,148,524$ \\
\hline TOTAL CASH OUT & $125,103,000$ & $242,876,225$ & $269,382,784$ & $300,092,565$ & $335,772,413$ & $377,338,199$ \\
\hline NET CASH FLOW & $125,103,000$ & $46,788,775$ & 49,331,966 & $\mathbf{5 0 , 5 8 9 , 3 9 7}$ & $50,087,844$ & $47,234,696$ \\
\hline
\end{tabular}

Tabel 5

Rekapitulasi Analisis Kelayakan Finansial

\begin{tabular}{|l|c|c|c|c|}
\hline \multicolumn{1}{|c|}{ Metode } & Hasil & \multicolumn{2}{c|}{ Indi Kator } & Kesimpulan \\
\hline Payback Period & 2 Tahun 2 Bulan & $<$ & 5 tahun & LAYAK \\
\hline Net Present Value & $\mathrm{Rp} 79,550,592$ & $>$ & 0 & LAYAK \\
\hline Interest Rate of Return & $27.23 \%$ & $>$ & $12.08 \%$ & LAYAK \\
\hline
\end{tabular}

\section{KESIMPULAN}

Beberapa faktor internal strategis baik berupa kekuatan maupun kelemahan yang terdapat dalam usaha budidaya Ayam Buras Brakel Kriel Silver dapat dijelaskan sebagai berikut :

1. Berdasarkan Analisis SWOT

a) Potensi lahan yang besar dengan bobot 0,15 (penting) dengan peringkat 4 (sangat tinggi) karena dengan potensi sebesar 9.970,5 Ha, maka akan memacu peluang usaha yang besar pula walaupun saat ini terdapat kendala dalam budidaya ayam buras brakel kriel silver namun akan dicari alternatif budidaya yang cocok dengan kondisi lingkungan.

b) Ketersediaan DOC yang memadai dengan bobot 0,05 (cukup penting) dengan peringkat 3 (tinggi) karena walaupun saat ini bibit Day Old Chick tersedia di sekitar Kota Palopo namun diduga mempunyai mutu yang kurang baik sehingga kurang tahan terhadap kondisi lingkungan kandang yang telah mengalami penurunan daya dukung lingkungan karena 
kebanyakan merupakan kandang bekas ayam ras yang dimanfaatkan kembali.

c) Jumlah tenaga kerja yang memadai dengan bobot 0,07 (cukup penting) dengan peringkat 3 (tinggi) karena dengan banyaknya angka usia kerja maka ketersediaan tenaga kerja terpenuhi.

d) Sarana dan prasarana produksi tersedia dengan bobot 0,10 (sangat penting) dengan peringkat 4 (sangat tinggi) karena dengan tersedianya sarana dan prasarana produksi budidaya ayam buras maka akan memberikan dorongan usaha yang besar walaupun usaha budidaya ayam buras brakel kriel silver saat ini belum dapat dilaksanakan secara maksimal, namun akan dicari solusi alternatif budidaya ayam buras yang memiliki nilai ekonomis yang cukup tinggi seperti persilangan ayam kampong super dengan ayam kampong yang memiliki karakteristik produktivitas telur tinggi dan tidak memiliki sifat mengeram seperti ayam buras jenis brakel kriel silver.

e) Ketersediaan modal dengan bobot 0,06 (cukup penting) dengan peringkat 2 (cukup tinggi) karena dengan ketersediaan modal yang cukup akan dapat meningkatkan usaha budidaya ayam buras dengan baik.

f) Dukungan Pemerintah besar dengan bobot 0,06 (cukup penting) dengan peringkat 2 (cukup tinggi) karena dukungan pemerintah sangat diharapkan dengan dilakukannya suatu penelitian, penyuluhan teknologi terbaru dalam usaha ternak ayam buras studi banding ke beberapa tempat yang telah berhasil dalam budidaya ayam buras diversifikasi kultivan selain jenis brakel kriel silver yang mempunyai nilai ekonomis yang cukup tinggi.

2. Berdasarkan Aspek Pasar, Aspek Teknis, Aspek Legal \& Lingkungan, Aspek SDM, dan Finansial usaha peternakan ayam buras layak sesuai kriteria kelayakan usaha.

3. Hasil perhitungan analisis sensitivitas menunjukkan bahwa usaha peternakan ayam buras tidak sensitif terhadap perubahan.

\section{Saran}

Saran yang dapat diajukan kepada Dinas Ketahan Pangan dan Dinas Pertanian dan peternakan Kota Palopo Palopo adalah untuk dapat memprioritaskan pasokan ayam buras dari dalam Kota Palopo. Sedangkan saran untuk para calon investor yang berminat membangun usaha peternakan ayam buras di Kota Palopo adalah, untuk dapat memanfaatkan lahan kosong yang tidak berfungsi untuk dijadikan area peternakan. Langkah-langkah pemecahan permasalahan dalam menghadapi kegagalan budidaya Ayam Buras di Kota Palopo, meliputi :

1. Untuk mengatasi sulitnya bibit unggul dan murni perlu dilaksanakan kerjasama dengan Dinas Pertanian dan Peternakan Kota Palopo

2. Perlu dilaksanakan pemberian kredit lunak kepada peternak ayam buras dengan paket saprodi melalui Program Pemberdayaan Ekonomi Masyarakat khusus peternak dan perlu dilanjutkan 
Beberapa faktor kemungkinan penyebab serangan penyakit pada ayam buras adalah sistem teknologi budidaya ayam buras selama ini tidak sesuai atau kurang ketelitian dalam pemilihan lokasi, kesalahan konstruksi dan strukturisasi, dan kualitas bibit DOC kurang baik dan terlalu jauh melampaui kapasitas kandang, Teknologi deteksi dan pencegahan penyakit. Peningkatan mutu melalui rekayasa genetika (reproduksi, pertumbuhan, mutu dan warna daging, efisiensi pakan, ketahanan terhadap penyakit dan perubahan lingkungan).

\section{REFERENCE}

Bakrie, B., D. Andayani, M. Yanis, dan D. Zainuddin. 2003. Pengaruh penambahan jamu ke dalam air minum terhadap preferensi konsumen dan mutu karkas ayam buras. hlm. 490-495. Prosiding Seminar Nasional Teknologi Peternakan dan Veteriner "Iptek untuk Meningkatkan Kesejahteraan Petani melalui Agribisnis Peternakan yang Berdaya Saing”. Bogor, 29-30 September 2003. Pusat Penelitian dan Pengembangan Peternakan, Bogor.

Crawford, R.D. 1990. Origin and history of poultry species. In : Poultry breeding and genetics. Elsevier, Amsterdam. Pp. 1-42

Fuadi, A. 2006. Analisis Permintaan Ayam Kampung oleh Restoran di Kotamadya Pontianak. Skripsi. Fakultas Peternakan Institut Pertanian Bogor

Griffin, Ricky. W dan Ebert, Ronald J. 2007. Bisnis. Edisi Kedelapan. Jilid 1. Penerbit Erlangga, Jakarta.

Gunawan. 2012. Evaluasi Model Pengembangan Usaha Ternak Ayam Buras dan Upaya Perbaikan. Disertasi. Program Pascasarjana Institut Pertanian Bogor.

Gunawan dan M.M.S. Sundari. 2003. Pengaruh penggunaan probiotik dalam ransum tehadap produktivitas ayam. Wartazoa 13(3):92-98.

Heizer, Jay \& Barry Render. 2006. Operations Management $7^{\text {th }} e d$. Salemba Empat: Jakarta

Kasmir dan Jakfar., 2012, Studi Kelayakan Bisnis, Edisi Revisi, Penerbit Kencana Prenada Media Grup, Jakarta.

Kompas. 2005. Wabah Flu Burung dan Karakter Investor Sejati, 28 Maret

Krugman, Paul R. 2003, Ekonomi Internasional; Teori dan Kebijakan, Raja Grafindo Pustaka: Jakarta

Lestari, S. 2000. Produktivitas Ayam Kampung di Dua Desa yang Berbeda Topografinya di Kabupaten Bogor. Skripsi. Fakultas Peternak an Institut Pertanian Bogor.

Marzuki. 2002. Metoda Riset. Bagian Penerbitan Fakultas Eonomi Universitas Islam Indonesia. Yogyakarta.

Mirzah, Mirzah and Adrizal, Adrizal and Montesqrit, Montesqrit 2009. Peningkatan Efisiensi Produksi Ayam Buras Melalui Penyempurnaan Sistem Produksi Dan Pemasaran Pada Sentra Produksiayam Buras Desa Kumbayau Sawahlunto. Working Paper. Lembaga Pengabdian Masyarakat. (Unpublished)

Ratih Dewanti dan Ginda Sihombing, 2012. Analisis Pendapatan Usaha Peternakan Ayam Buras Studi Kasus di Kecamatan Tegalombo, Kabupaten Pacitan. Buletin Peternakan Vol. 36(1): 48-56

Sartika. T. 2005. Peningkatan Mutu Bibit Ayam Kampung melalui Seleksi dan Pengkajian Penggunaan Penanda Genetik Promotor Prolaktin dalam MAS/Marker Assiated Selection untuk Mempercepat Proses Seleksi. Disertasi. Sekolah Pascasarjana Institut Pertanian Bogor.

Siregar, Ali Basyah., 2009. Analisis Kelayakan Pabrik, Institut Teknologi Bandung, Bandung. 
Sarwono, B. 2012. Beternak Ayam Kampung. Tarsito, Bandung.

Subagyo, Ahmad. 2007. Studi Kelayakan Bisnis. Cetakan Kedua. PT. Elex Media Komputindo, Kelompok Gramedia, Jakarta.

Sugiyono, 2008. Metode Penelitian Bisnis.Alfabeta, Bandung

Sulandari, S., M.S.A. Zein, S. Priyanti, T. Sartika, M. Astuti, T. Widjastuti, E. Sujana, S. Darana, I. Setiawan, dan G. Garnida. 2007. Sumbedaya genetik ayam lokal Indonesia. hlm. 45-104. Dalam Keanekaragaman Sumber Daya Hayati Ayam Lokal lndonesia: Manfaat dan Potensi. Pusat Penelitian Biologi, Lembaga IImu Pengetahuan Indonesia, Bogor.

Ernie T dan Saefullah, Kurniawan. 2005. Pengantar Manajemen. Cetakan Pertama. Kencana, Prenada Media Group, Jakarta.

Rasyid, T.G. 2002. Analisis perbandingan keuntungan peternak ayam buras dengan sistem pemeliharaan yang berbeda. Bulletin Nutrisi dan Makanan Ternak 3(1): 15-22.

Rohaeni, E.S., D. Ismadi, A. Darmawan, Suryana, dan A. Subhan. 2004. Profil usaha peternakan ayam lokal di Kalimantan Selatan (Studi kasus di Desa Murung Panti Kecamatan Babirik, Kabupaten Hulu Sungai Utara dan Desa Rumintin Kecamatan Tambarangan, Kabupaten Tapin). hlm. 555-562. Prosiding Seminar Nasional Teknologi Peternakan dan Veteriner 2004. Buku II. Bogor, 4-5 Agustus 2004. Pusat Penelitian dan Pengembangan Peternakan, Bogor

Umar, Husein. 2005. Studi Kelayakan Bisnis. Edisi Ketiga. Gramedia Pustaka Utama, Jakarta.

Yuwanta, T., M.A. Wiguna, dan K.A. Santosa. 2009. Pemberdayaan Masyarakat dalam Pembesaran dan Penggaduhan Ayam Buras Sistem Bobot Badan Sebagai Usaha Mengatasi Krisis Ekonomi di Desa Kalibening, Kec. Kalasan, Kab. Sleman. LPM. Universitas Gadjah Mada, Yogyakarta.
Zakaria, S. 2004. Pengaruh luas kandang terhadap produksi dan kualitas telur ayam buras yang dipelihara dengan sistem litter. Bulletin Nutrisi dan Makanan Ternak 5(1): $1-11$.

Zakaria, S. 2004. Performansi ayam buras fase dara yang dipelihara secara intensif dan semiintensif dengan tingkat kepadatan kandang yang berbeda. Bulletin Nutrisi dan Makanan Ternak 5(1): 41-45. 